\title{
PERANCANGAN SISTEM INFORMASI GAJI KARYAWAN STUDI KASUS :PT. CAHAYA FAJAR SODIQ
}

\author{
Ofah Musyarrofah ${ }^{1}$ \\ Rudy Rachmat Darmawan ${ }^{2}$ \\ Rexa Subarkah ${ }^{3}$ \\ Jl. Jendral Sudirman No. 40, Modernland, Tangerang \\ Email : ofahmusyarrofah@raharja.info, rudy.darmawan@raharja.info, rexa.subarkah@ raharja.info
}

\begin{abstract}
ABSTRAK
PT.Cahaya Fajar Sodiq (PT.CFS) adalah suatu Persero yang bergerak dibidang jasa kontraktor, perdagangan umum, diwilayah Cigading Ciwandan. Gaji merupakan hak yang dimiliki oleh karyawan disetiap perusahaan manapun yang harus dibayarkan dalam setiap jangka waktu tertentu sesuai dengan perjanjian dan ketetapan yang berlaku disebuah perusahaan. Penelitian yang dilakukan untuk menganalisa sistem gaji karyawan yang saat ini masih manual, belum terkomputerisasi dengan baik, karena terbatasnya pengetahuan tentang sistem database dan aplikasi komputer sehingga menyebabkan permasalahan dalam perekapan perhitungan dan keakuratan informasi penggajian, metode yang digunakan dari permasalahan tersebut adalah dengan merancang bangun sistem gaji karyawan sesuai dengan sistem yang dibutuhkan.Dengan adanya rancang bangun dan implementasi sistem gaji diharapkan memberikan solusi yang lebih efisien dalam perhitungan gaji karyawan dengan cepat. Dengan prinsipprinsip tersebut, diharapkan dapat memberikan kemudahan pada user dalam menyampaikan permasalahanya serta memudahkan untuk identifikasi permasalahan sehingga dapat mewujudkan efisiensi dan efektifitas pelayanan $u$ ser.
\end{abstract}

Kata Kunci: perancangan, sistem, gaji, karyawan,

\begin{abstract}
PT. Cahaya Fajar Sodiq (PT. CFS) is a company which runs in the sector of contractor service and general trading at the area of Cigading Ciwandan. Salary is a right belonging of each employee in any company which must be paid in a certain period accordance with the agreement and applied regulation in a company. The goal of this research is to analyze the system of employee salary which is still manually and has not computerized owing to lack of knowledge about database system and computer application which causes issue in calculation and the information accuracy. The method which is used from this issue by constructing the system of employee salary accordance with the required system. By constructing and implementing the salary system, it is expected giving solution which is more efficient to calculate employee salary quickly. By applying them, user is expected able to convey their issue easily and it can be able to identify the issue easier so that it can actualize the efficiency and effectivity of user service.
\end{abstract}

Keyword: design, system, salary, employee 


\section{PENDAHULUAN}

Gaji adalah hak yang dimiliki oleh setiap karyawan disetiap Perseroan, yang diberikan secara teratur dalam jangka tertentu sesuai dengan undang-undang perusahaan kepada karyawan atas jasa dan hasil kerjanya pada perusahaan. Gaji disebut juga sebagai upah, dimana keduanya merupakan suatu bentuk kompensasi, yakni imbalan jasa yang diberikan secara teratur atas prestasi kerja yang diberikan kepada karyawan. Perbedaan gaji dan upah hanya terletak pada kuatnya ikatan kerja dan jangka waktu penerimaannya. Besarnya gaji yang diberikan kepada seorang karyawan biasanya sangat tergantung dari latar belakang pendidikan yang dimiliki, kemampuan maupun pengalaman kerjanya.sistem dengan pendekatan prosedur yaitu : "Sistem adalah suatu jaringan prosedur yang dibuat dengan pola yang terpadu untuk melaksanakan kegiatan pokok perusahaan ". (Mulyadi, $2008: 5$ ) dan dalam pengertian lain "Sistem merupakan serangakaian bagian yang saling tergantung dan bekerjasama untuk mencapai tujuan tertentu". (Diana, Setiawati, $2011: 3$ ) dapat disimpulkan bahwa sistem merupakan sesuatu atau unsur yang memiliki bagian atau komponen yang saling berhubungan satu sama lain dan memiliki tujuan akhir yang sama.

Informasi merupakan hal yang sangat penting bagi pihak manajemen dalam mengambil keputusan, sehingga informasi menjadi hal yang sangat penting didalam suatu organisasi. Pengertian informasi menurut Robert N Anthony, John Dearden yaitu " Informasi adalah data yang diolah menjadi bentuk yang lebih berguna dan lebih berarti bagi yang menerimanya “.(Jogiyanto HM, 1995 : 8) Sumber informasi adalah data, data adalah kenyataan yang menggambarkan suatu kegiatan-kegiatan dari kesatuan nyata tetapi data merupakan bentuk data mentah yang belum dapat dimengerti bagi pemakainya sehingga data perlu diolah terlebih dahulu untuk memperoleh informasi yang dibutuhkan.

Pengertian sistem informasi menurut Robert A Leitch dan K. Rascoe Davis adalah : "Sistem Informasi adalah suatu sistem didalam suatu organisasi yang mempertemukan kebutuhan pengolahan transaksi harian, mendukung operasi, bersifat manajerial dan kegiatan strategi dari suatu organisasi dan menjadikan pihak luar tertentu dengan laporan laporan yang diperlukan ". (Jogiyanto HM,1995 : 1) dari pernyataan tersebut dapat disimpulkan sistem informasi sebagai mekanisme dari suatu upaya manajemen yang dimaksudkan untuk meningkatkan mutu suatu sistem informasi yang lebih berguna bagi penerimanya

Penggajian karyawan pada PT. Cahaya Fajar Sodiq diberikan berdasarkan pada masingmasing jabatan setiap karyawan. Setiap karyawan memperoleh beberapa tunjangan seperti tunjangan anak, tunjangan transport dan tunjangan istri. Semua tunjangan itu digabungkan dengan gaji pokok yang telah ditetapkan dan dipotong oleh potongan pinjaman, maka gajinya dipotong oleh pinjaman. "Gaji adalah imbalan kepada pegawai yang diberikan atas tugas-tugas administrasi dan pimpinan yang jumlahnya biasanya tetap secara bulanan". (Soemarso 2009 : 307 ) Sedangkan pendapat lain menyatakan gaji adalah: "Gaji umumnya merupakan pembayaran atas penyerahan jasa yang dilakukan oleh karyawan yang mempunyai jenjang jabatan manajer". (Mulyadi, 2008 : 373 ) "Gaji adalah sebuah bentuk pembayaran atau sebuah hak yang diberikan oleh sebuah perusahaan atau instansi kepada pegawai”. (Mardi, 2011 : 107 ) 


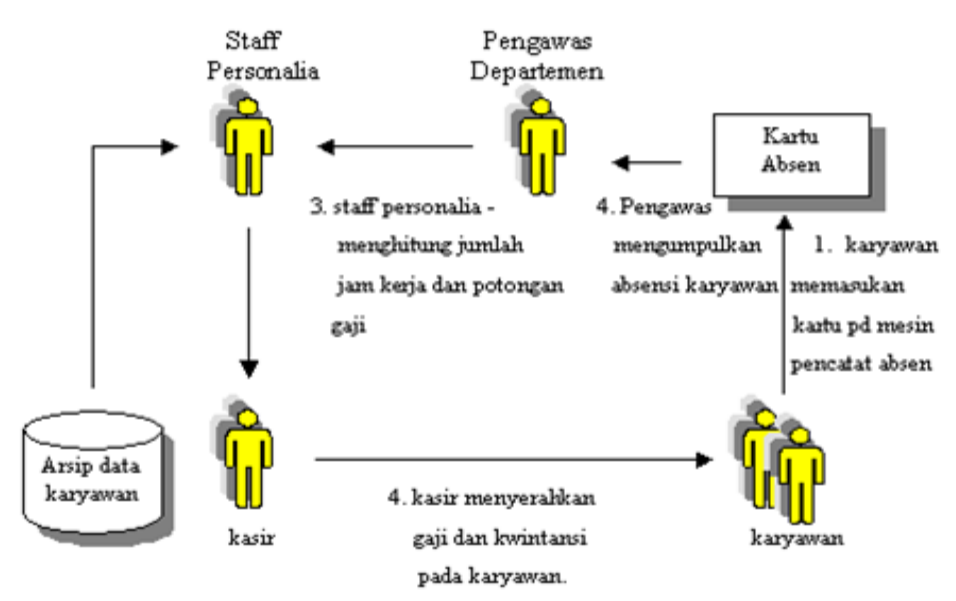

Gambar 1. Siklus pendataan gaji karyawan

Karyawan adalah orang yang bekerja disuatu lembaga perusahaan dengan mendapatkan gaji atau upah yang diberikan dalam jangka waktu tertentu menurut perjanjian yang ada

"Karyawan adalah setiap orang yang bekerja dengan menjual tenaganya (fisik dan pikiran) kepada suatu perusahaan dan memperoleh balas jasa yang sesuai dengan perjanjian. Sedangkan menurut kamus besar bahasa Indonesia karyawan merupakan orang yang bekerja pada suatu lembaga (kantor, perusahaan) dengan mendapatkan gaji”. (Hasibuan, 2007:117)

Fungsi Kepegawaian bertanggung jawab untuk mencari karyawan baru, menyeleksi calon karyawan, memutuskan penempatan karyawan baru, membuat surat keputusan tarif gaji dan upah karyawan, kenaikan pangkat dan golongan gaji, mutasi karyawan, dan pemberhentian karyawan. Dalam struktur organisasi pada fungsi kepegawaian berada ditangan Bagian kepegawaian, dibawah Departemen Personalia dan Umum.

Fungsi Keuangan bertanggung jawab untuk mengisi cek guna pembayaran gaji dan menuangkan cek tersebut ke bank. Uang tunai tersebut kemudian dimasukan ke dalam amplop gaji setiap karyawan, untuk selanjutnya dibagikan kepada karyawan yang berhak.

\section{PERMASALAHAN}

Permasalahan yang terjadi dari pernyataan diatas maka sistem gaji saat yang digunakan masih manual dan sering terjadi kekeliruan dalam perekapan perhitungan dan keakuratan informasi gaji karyawan sehingga diperlukan sistem informasi gaji karyawan yang sesuai dan tepat guna dalam sistem gaji karyawan pada PT.CFS

\section{CRITICAL REVIEW}

Merancang sistem yang tepat guna dalam sistem gaji karyawan merupakan solusi yang tepat dari permasalahan yang ada, dengan membangun sistem yang lebih mempuni dan efisien dalam pendataan gaji karyawan sehingga data yang didapat lebih akurat. Dengan menggunakan software yang lebih menunjang akan sangat membantu, dengan menggunakan database sql 
server dan pemprograman Visual Basic kinerja yang dihasilkan akan lebih cepat dan akurat. Dengan sistem gaji yang terkomputerisasi akan menjadi solusi yang tepat guna

Pemprograman Visual Basic adalah bahasa pemprograman yang friendly mudah digunakan dan support dengan beberapa database sehingga lebih mudah dirancang dan dikembangkan sebagai contoh, jika user menggunakan sistem operasi $M S$ Windows yang terpasang di komputernya, maka user tersebut dapat pula menggunakan pemprograman dan database tersebut dalam satu komputer.

\section{PEMECAHAN MASALAH}

Dalam penulisan artikel ini digunakan beberapa metode penyelesaian masalah dengan tahapan sebagai berikut:

a. Planning:

- Menentukan aplikasi yang akan digunakan contoh pemprograman Visual Basic dan database sql server

- Memilih hardware yang lebih menunjang dalam pembangunan sistem.

b. Analisis:

- Membandingkan sistem yang sedang berjalan dengan sistem yang diusulkan

c. Desain:

- Perancangan dilakukan dengan menggunakan bahasa pemprograman dan sql server.

d. Implementasi:

- Implementasi dilakukan dengan cara memanfaatkan sistem yang dibangun untuk sistem gaji

\section{IMPLEMENTASI DAN PEMBAHASAN}

Dalam implementasi, artikel ini menjelaskan bahwa instalasi aplikasi sistem gaji menggunakan pemprograman Visual Basic dikarenakan pemprograman Microsoft Visual Basic sebuah bahasa pemrograman yang menawarkan Integrated Development Environment visual untuk membuat program perangkat lunak berbasis sistem operasi Microsoft Windows Visual Basic adalah turunan bahasa pemrograman BASIC dan menawarkan pengembangan perangkat lunak komputer grafik dengan cepat, dapat menggunakan komponen-komponen yang disediakan oleh Microsoft Visual Basic Program-program yang ditulis dengan Visual Basic dapat menggunakan Windows API, dengan membutuhkan deklarasi fungsi luar tambahan. Visual Basic merupakan salah satu tool untuk pengembangan aplikasi yang banyak diminati karena menawarkan kemudahan dalam pembuatan aplikasi dan dapat menggunakan komponenkomponen yang telah disediakan aplikasi yang mengintegrasikan database, jaringan, office automation, dan web application. 


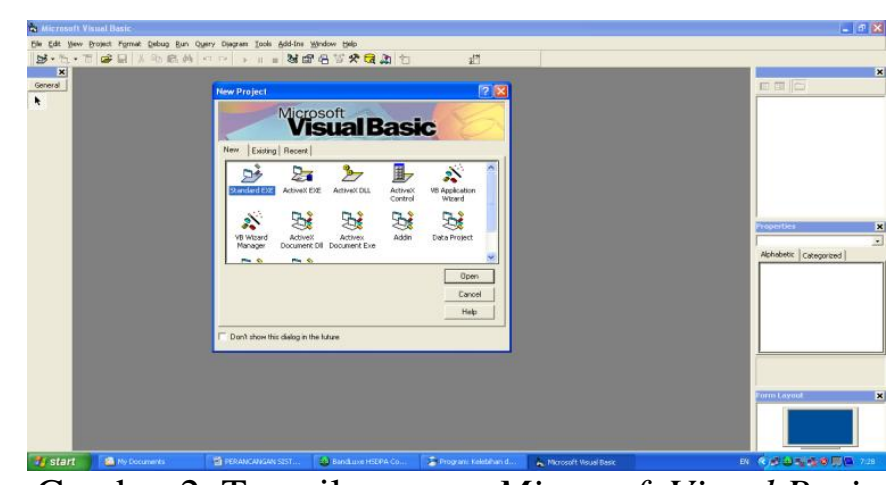

Gambar 2. Tampilan menu Microsoft Visual Basic

Pemprograman Visual Basic membutuhkan database sebagai media penyimpanan data dengan kapasitas besar sehingga didukung menggunakan software lain dengan Sql Server Sql Server merupakan suatu sistem manajemen basis data relasional yang dirancang untuk aplikasi dengan bentuk arsitekturclient-server, Sql Server banyak digunakan oleh programmer karena mudah digunakan. MySQL dapat berjalan di berbagai sistem operasi dan berikut adalah tampilan menu Sql Server.

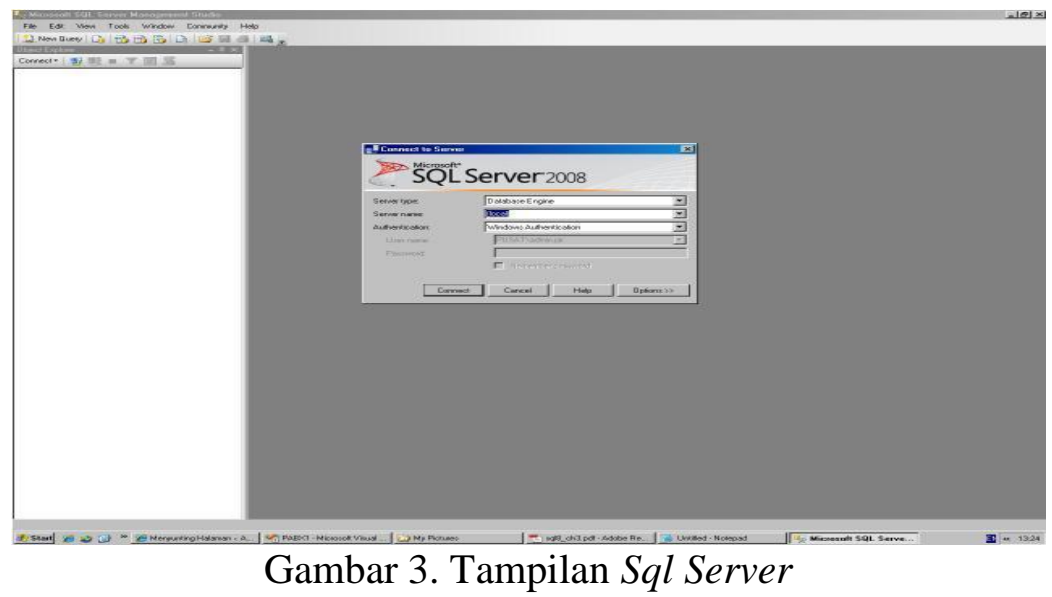

Setelah terinstalasi Sql Server maka dapat dibangun untuk membuat database yang akan dirancang untuk membuat sistem informasi gaji karyawan dengan mendukung pemprograman Visual Basic, bagaimana Sql Server dijalankan maka tampilan create table guna menunjang sistem gaji dapat dilihat pada gambar dibawah ini. 
ISSN : 2356 - 5195



Gambar 4. Tampilan layout design

Setelah terinstal software software yang menunjang, langkah selanjutnya adalah mulai mendesain dan merancang sistem gaji dan berikut rancangan Entity Relationship Diagram sistem gaji pada PT.CFS

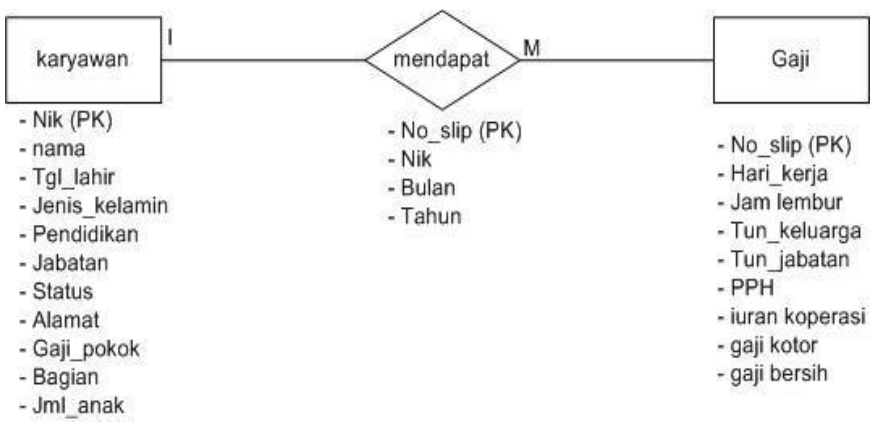

Gambar 5. Entity Relationship Diagram

Setelah merancang Entity Relationship Diagram tahap selanjutnya mulai membuat rancangan diagram overview guna mempermudah membangun sistem gaji dengan merancang diagram overview maka akan terlihat jelas alur dalam membangun sistem dan berikut rancangan diagram overview 


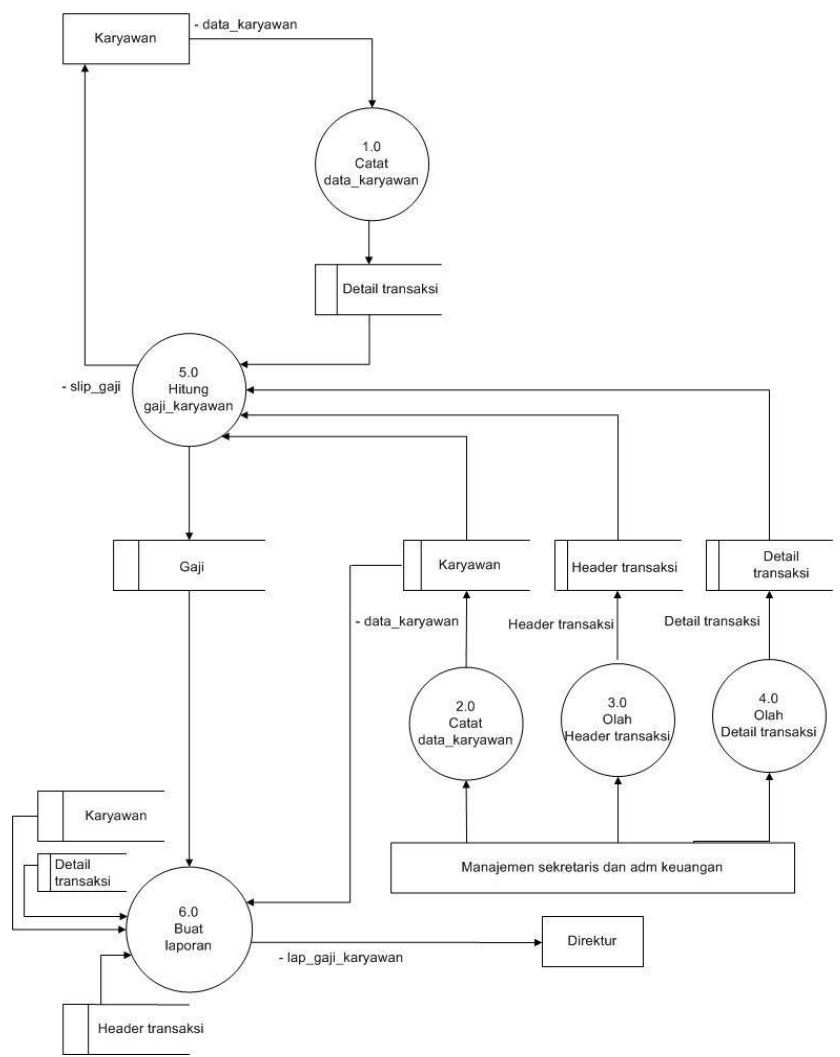

Gambar 6. Diagram Overview

\section{LISTING PROGRAM}

Private Sub Form_Load()

TMaxAni1.FileName = App.Path + "'sih.gif"

TMaxAni1.ShowGif

End Sub

Private Sub Timer1_Timer()

bar. Value $=$ bar. Value +2

If bar. Value $=100$ Then

If Timer1.Interval $>=1$ Then

Unload loading

Load Login

Login.Show

End If

End If

End Sub

Option Explicit

Dim a As Integer

Private Sub Cmd_Batal_Click()

mEnU.MsData.Enabled $=$ False

mEnU.MnPros .Enabled $=$ False 


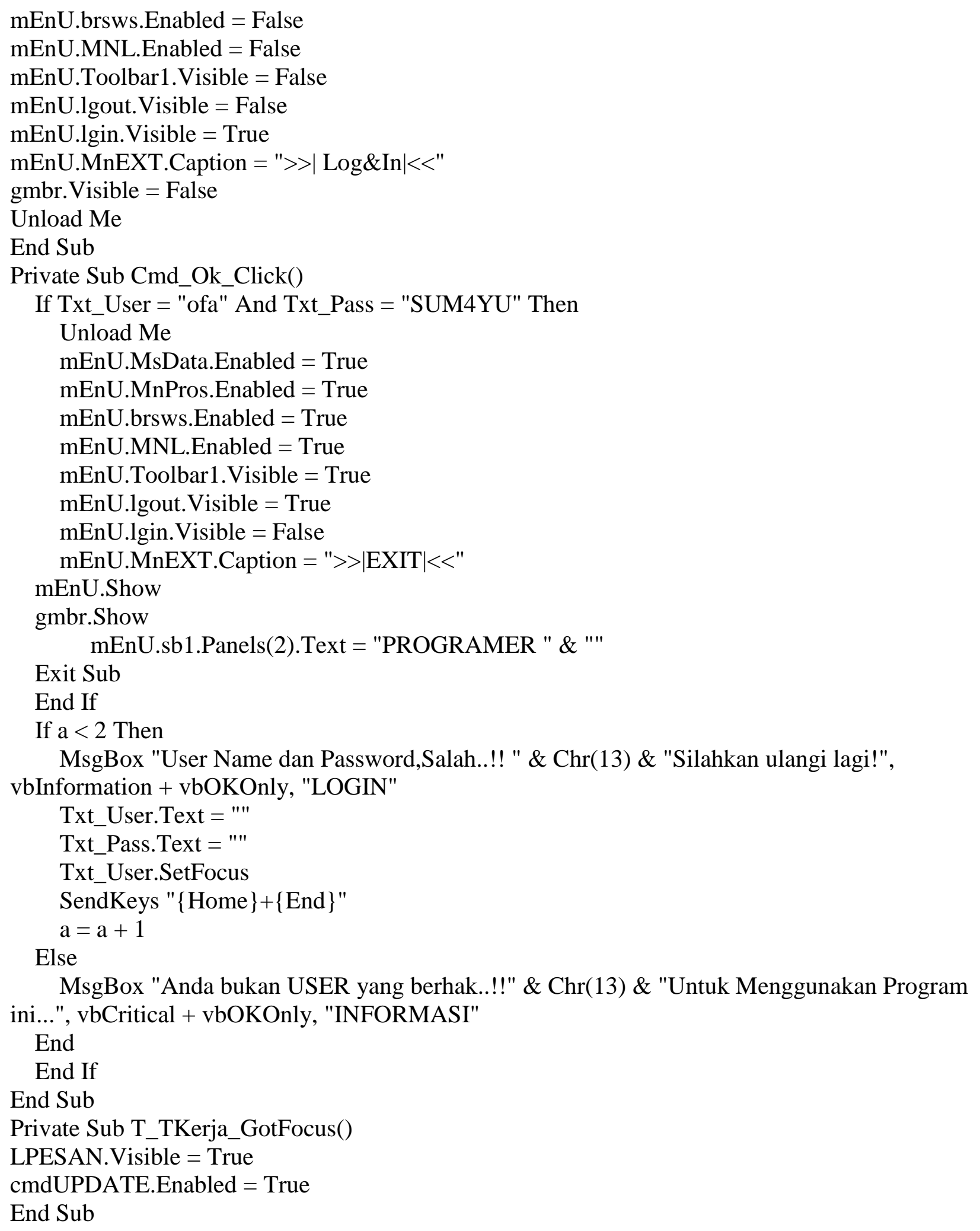


Private Sub T_TKerja_KeyPress(KeyAscii As Integer)

If KeyAscii = 13 Then

If T_TKerja.Text $=$ "" Then

MsgBox "Jumlah Hari Tidak Kerja" \& Chr(13) \& " Masih kosong..!!", vbOKOnly + vbCritical, "PERHATIAN"

T_TKerja.Refresh

T_TKerja.SetFocus

Else

TOTAL $=$ Val(L_Hker.Caption) - Val(T_TKerja.Text $)$

L_TotKer.Caption $=$ TOTAL

GABER $=$ Val(TOTAL) $* \operatorname{Val}($ CnGaTor("GAJI_POKOK"))

L_GR.Caption $=$ GABER

CMDSIMPAN.Enabled $=$ True

End If

End If

End Sub

Private Sub cmdUPDATE_Click()

With CnGaBer

.Clone

T_NIP.Text $=$ !nip

L_NAMA.Caption $=$ !nama

L_BAGIAN.Caption $=$ !bagian

L_JABATAN.Caption $=$ ! jabatan

L_GAPOK.Caption = Val(!GAJI_KOTOR)

L_TUNJAB.Caption $=$ Val(!TUNJ_JAB $)$

L_KELUARGA.Caption = Val(!tunj_anak)

T_LAIN1.Text = Val(!lain)

L_TOTPEND.Caption $=$ Val $($ !pendapatan $)$

L_PPH21.Caption $=$ Val $(! p p h)$

T_IURAN.Text $=$ Val(!iuran_koperasi)

T_LAIN2.Text $=$ Val(!lain2)

L_TOTPENG.Caption = Val(! pengeluaran $)$

L_GABER.Caption = Val(!GABER $)$

cBln. Text $=$ !Bulan

tTh. Text $=$ !Tahun

.update

End With

CnGaBer.Requery

BERSIH

T_NIP.Text $=$ ""

T_NIP.SetFocus

cmdUPDATE. Enabled $=$ False

CMD_EDIT.Enabled $=$ True 
End Sub

Private Sub Form_Activate()

T_NIP.MaxLength $=6$

T_NIP.SetFocus

cmdBERSIH.Enabled $=$ False

CMD_EDIT.Enabled $=$ False

End Sub

Private Sub Form_Load()

cBln.Clear

tTh.Text = ""

End Sub

Private Sub T_IURAN_KeyDown(KeyCode As Integer, Shift As Integer)

If KeyCode $=13$ Then

T_LAIN2.SetFocus

End If

End Sub

Private Sub T_LAIN1_KeyDown(KeyCode As Integer, Shift As Integer)

If KeyCode $=13$ Then

TOT_PEND $=$ Val(L_GAPOK.Caption $)+$ Val(L_TUNJAB.Caption $)+$

Val(L_KELUARGA.Caption) + Val(T_LAIN1.Text)

L_TOTPEND.Caption $=$ TOT_PEND

PPH21 = $(15 / 100) *$ TOT_PEND

L_PPH21.Caption $=$ PPH21

T_IURAN.SetFocus

End If

End Sub

Private Sub T_LAIN2_KeyPress(KeyAscii As Integer)

If KeyAscii $=13$ Then

TOT_PENG $=$ PPH21 + Val(T_IURAN.Text $)+$ Val $\left(T \_L A I N 2 . T e x t\right)$

L_TOTPENG.Caption $=$ TOT_PENG

TOT_BERSIH $=$ TOT_PEND - TOT_PENG

L_GABER.Caption = TOT_BERSIH

CMDSIMPAN.Enabled $=$ True

CMD_EDIT. Enabled $=$ False

End If

End Sub

Sub Simpan()

With CnGaBer

.AddNew

!nip = Val(T_NIP.Text)

!nama $=$ L_NAMA.Caption

!bagian $=$ L_BAGIAN.Caption

!jabatan $=$ L_JABATAN.Caption 


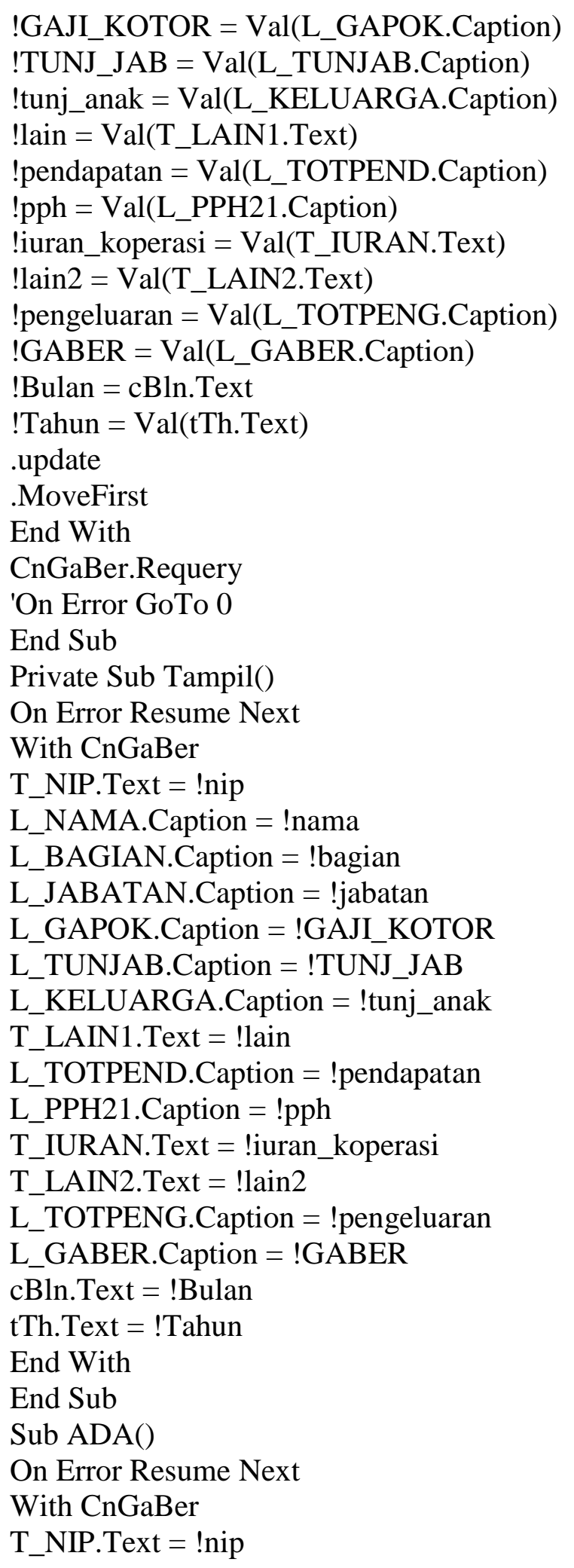


L_NAMA.Caption $=$ !nama

L_BAGIAN.Caption $=$ ! bagian

L_JABATAN.Caption $=$ ! jabatan

L_GAPOK.Caption = Format(!GAJI_KOTOR, "\#,\#,0")

L_TUNJAB.Caption = Format(!TUNJ_JAB, "\#,\#,0")

L_KELUARGA.Caption = Format (!tunj_anak, "\#,\#,0")

T_LAIN1.Text = Format(!lain, "\#,\#,0")

L_TOTPEND.Caption = Format (!pendapatan, "\#,\#,0")

L_PPH21.Caption = Format (!pph, "\#,\#,0")

T_IURAN.Text = Format(!iuran_koperasi, "\#,\#,0")

T_LAIN2.Text = Format(!lain2, "\#,\#,0")

L_TOTPENG.Caption = Format(!pengeluaran, "\#,\#,0")

L_GABER.Caption = Format (!GABER, "\#,\#,0")

cBln. Text $=$ !Bulan

tTh. Text $=$ !Tahun

End With

End Sub

Sub TAMPILKAN()

On Error Resume Next

With CnQh_Ber

T_NIP.Text $=$ CnQh_Ber!nip

L_NAMA.Caption $=$ CnQh_Ber!nama

L_BAGIAN.Caption $=$ CnQh_Ber!bagian

L_JABATAN.Caption $=$ CnQh_Ber!jabatan

L_GAPOK.Caption $=$ CnQh_Ber!GAJI_KOTOR

L_TUNJAB.Caption $=$ CnQh_Ber!TUNJ_JAB

L_KELUARGA.Caption $=$ CnQh_Ber!tunj_anak

End With

End Sub

Private Sub T_NIP_Change()

If Len(T_NIP.Text) $<6$ Then

Exit Sub

End If

On Error Resume Next

CnGaTor.Find "nip="' \& T_NIP.Text \& "'", , adSearchForward, 1

If Not CnGaTor.EOF Then

PERIOD

TAMPILKAN

cmdBERSIH.Enabled $=$ True

CMD_EDIT.Enabled $=$ True

Else

If CnGaTor.EOF Then

CLEAN 
MsgBox "Nomor Induk Pegawai [" \& T_NIP.Text \& "]" \& Chr(13) \& "==> Tidak Ada..!!<<==" \& Chr(13) \& "Inputkan Data Karyawan Terlebih Dahulu...!", vbOKOnly + vbInformation, "INFORMASI"

T_NIP.Text $=$ ""

T_NIP.SetFocus

cmdBERSIH.Enabled $=$ False

CMD_EDIT. Enabled $=$ False

End If

End If

End Sub

Private Sub T_NIP_KeyPress(KeyAscii As Integer)

If KeyAscii = 13 Then

T_LAIN1.SetFocus

Exit Sub

End If

If Not (KeyAscii >= Asc("0") And KeyAscii <= Asc("9") Or_

KeyAscii $=$ vbKeyBack) Then

Beep

KeyAscii $=0$

MsgBox "NIP.. Type Data Angka!", 0, "KESALAHAN"

T_NIP.Text = ""

Exit Sub

End If

End Sub

Instalasi aplikasi dan alur sistem sudah dirancang tahap berikutnya mendesain sistem dengan fasilitas Visual Basic untuk membuat menu loading sistem dan berikut tampilan menu loading sistem gaji pada PT.CFS

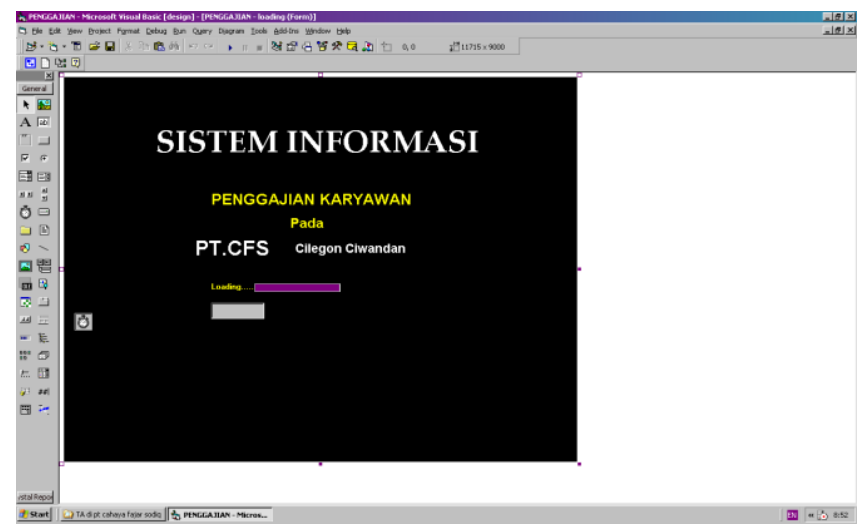

Gambar 7. Tampilan loading sistem 
Langkah awal dari pembangunan sistem gaji adalah dengan membuat menu loading dan tahap selanjutnya adalah membuat menu login dan berikut adalah tampilan login pada sistem gaji

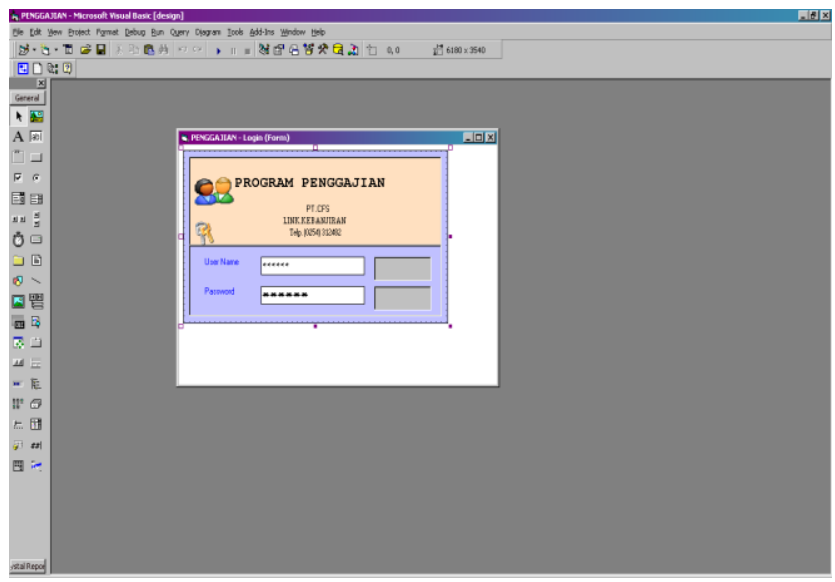

Gambar 8. Menu login

Maka setelah dibuat menu login user tahap selanjutnya membuat menu utama sistem yang terdiri dari menu karyawan, menu tunjangan dan menu gaji dan berikut tamplan menu utama dari sistem gaji pada PT.CFS

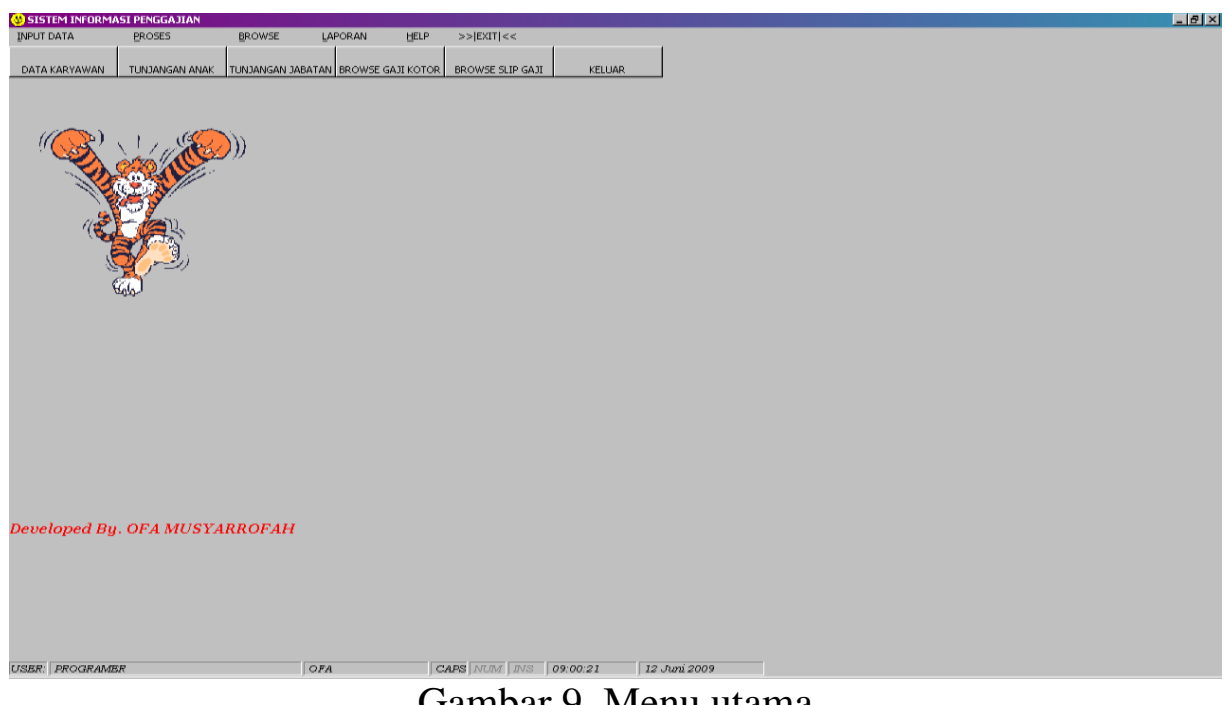

Gambar 9. Menu utama

Pada gambar 9 menunjukkan menu utama berfungsi sebagai form utama yang didesain untuk menampilkan form-form yang ada seperti form karyawan, form transaksi, proses proses dan input data serta atribut lain yang menjadi komponen menu dari menu utama. Tahap selanjutnya mendesain menu karyawan dan berikut tampilannya 


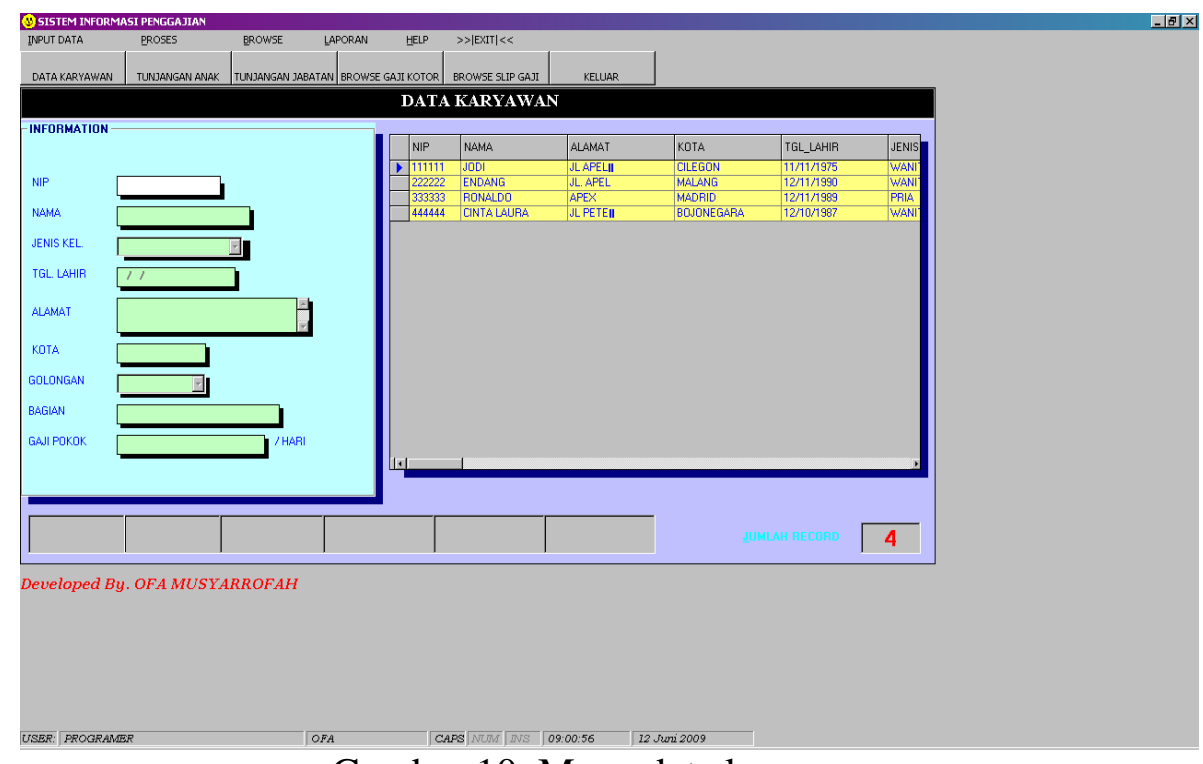

Gambar 10. Menu data karyawan

Menu data karyawan difungsikan untuk menginput data karyawan guna perekapan gaji yang akan diberikan sesuai dengan ketentuan disamping itu dalam perhitungan gaji karyawan karyawan memiliki beberapa tunjangan yang menjadi tambahan dalam memperoleh gaji diantaranya tunjangan jabatan dan tunjangan anak dan berikut desain menu tunjangan tersebut.

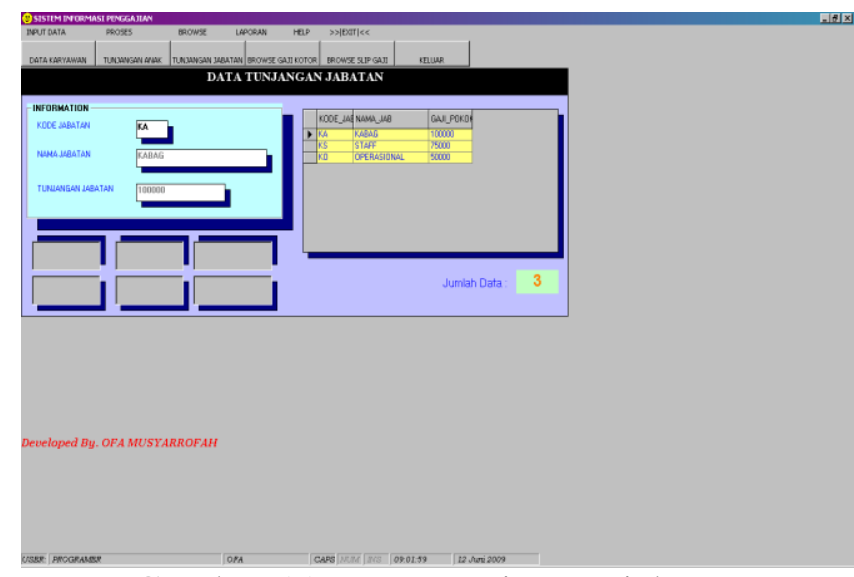

Gambar 11. Menu tunjangan jabatan

Disamping tunjangan jabatan yang dimiliki oleh setiap karyawan masih ada tunjangan anak yang dapat diperhitungkan dalam perolehan gaji pegawai dan berikut adalah menu tunjangan anak 


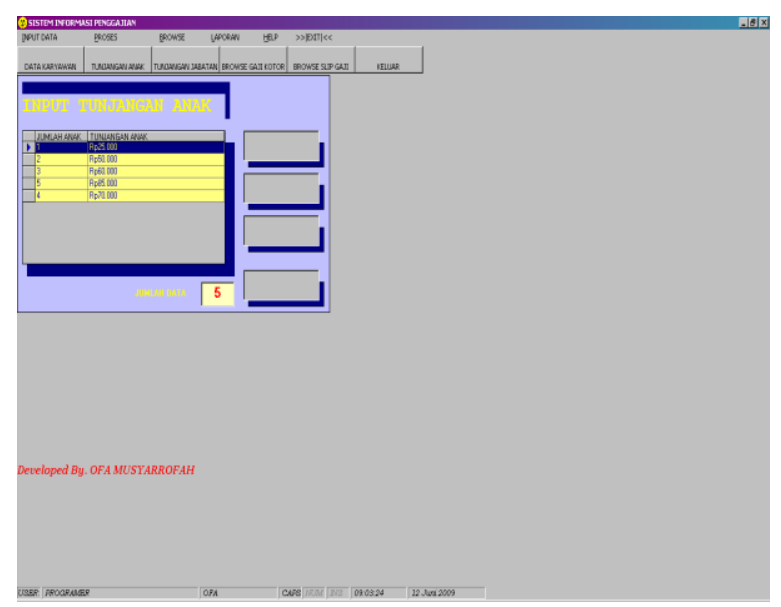

Gambar 12. Menu tunjangan anak

\section{IMPLEMENTASI}

Setelah mendesain menu yang dibutuhkan dalam membangun sistem gaji maka dilakukan implementasi sistem tersebut dan berikut beberapa tampilan menu lain sistem gaji

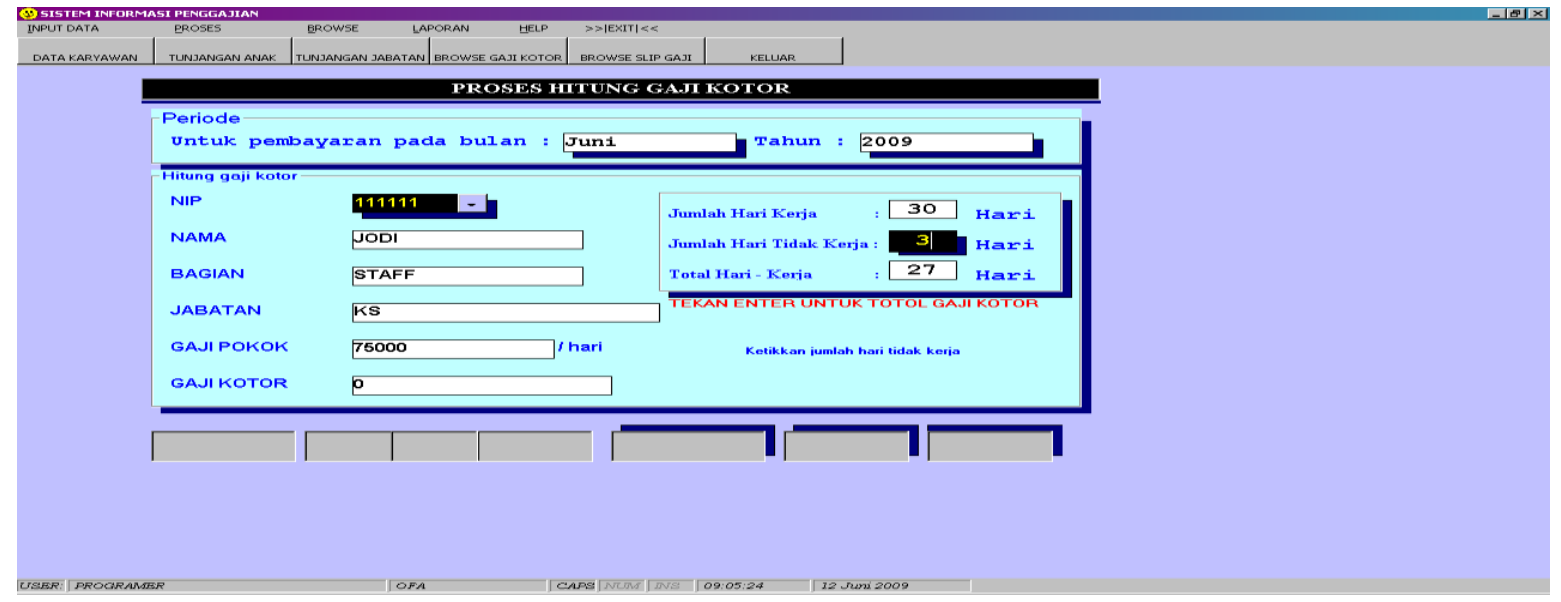

Gambar 13. Menu perhitungan gaji kotor

Menu Form hitung data gaji kotor adalah data digunakan untuk menghitung data gaji kotor karyawan, Tampilan ini hasil dari penginputan data gaji kotor karyawan, daftar data yang sudah dimasukan oleh administrasi keuangan. Perhitungan gaji kotor dihitung sebelum melakukan proses perhitungan gaji bersih karyawan pada sistem penggajian yang dilakukan setiap bulan . 


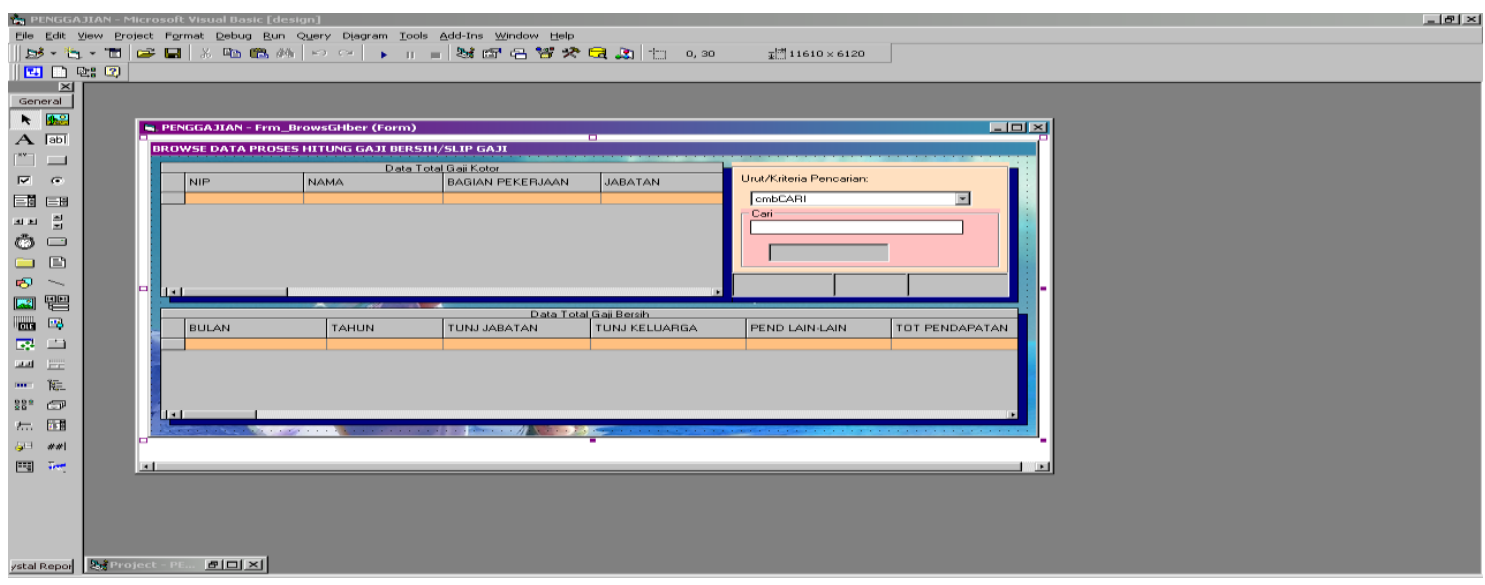

Gambar 14. Menu perhitungan gaji kotor

Setelah dilakukan perhitungan sistem gaji makan dipeoleh gaji bersih yang akan dipeoleh karyawan dan berikut slip gaji setelah dilakukan rekap gaji pada PT. CFS

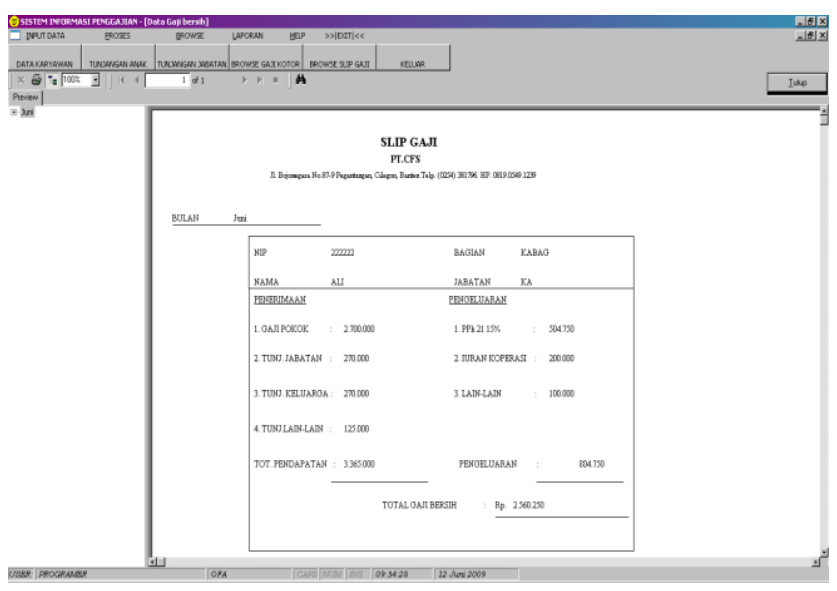

\section{KESIMPULAN}

Berdasarkan analisa perancangan Sistem Informasi Penggajian Karyawan PT. Cahaya Fajar Sodiq di Cilegon, dapat disimpulkan sebagai berikut :

Dengan adanya Sistem Informasi Penggajian Karyawan maka diharapkan penginputan data yang dilakukan dapat terkontrol dengan baik dan cepat. sistem yang telah tersusun maka informasi pelayanan operasional informasi sistem gaji yang dihasilkan sudah berjalan dengan cepat dan tepat, tidak memerlukan waktu yang lama dan informasi yang didapat lebih akurat. pembuatan laporan dalam sistem ini berjalan sangat cepat dan akurat hal ini disebabkan telah disusunnya media penyimpanan yang baik sesuai dengan kebutuhkan. 


\section{SARAN}

Setelah melakukan analisa terhadap perancangan sistem informasi gaji PT.CFS, maka ada beberapa saran yang perlu disampaikan agar sistem yang baru berjalan secara optimal, yaitu : Perlu diadakan pelatihan user bagian pelayanan operasional penginputan data yang bertanggung jawab dan berwenang dalam pengoprasian sistem ini. dengan sistem perancangan database yang terkomputerisasi, diusahakan dalam pemakaiannya melaksanakan tugas dengan penuh tanggung jawab dan dalam proses penginputan datanya harus dilakukan secara teliti dan seksama karena walaupun dengan sistem komputerisasi bila input datanya salah maka outputnya pun akan salah pula sehingga menimbulkan ketidak akuratan dalam pemberian informasi

\section{DAFTAR PUSTAKA}

[1] H.M, Jogiyanto, Akt, Mba, Ph. D. 2010. Analisa Dan Desain. Yogyakarta: andi

[2] Kadir, Abdul. 2014. Pengenalan Sistem Informasi. Yogyakarta : andi

[3] Kristanto, Harianto, Ir.1993. Konsep Dan Perancangan Database, Edisi 1. Yogyakarta : andi

[4] D. Suryadi H.S,.1996. Pengantar Struktur Data, Edisi 2. Jakarta : Universitas Gunadarma

[5] Kurniadi, Adi. 2011. Pemrograman Microsoft Visual Basic 6. Jakarta: PT Elex Media Komputindo.

[6] Daryanto, Drs, 2006. Belajar Komputer Visual Basic. Malang : YRAMA WIDYA

[7] Mulyadi, 2008. Sistem Akuntansi, Edisi. Jakarta : Salemba Empat

[8] Hasibuan 2007. Manajemen Sumber Daya Manusia. Cetakan 9. Jakarta : PT. Bumi Aksara

[9] Suryabrata, Sumadi.2010.Metodologi Penelitian.Jakarta: PT. Raja Grafindo Persada

[10] Diana, setiawati. 2011. Sistem Informasi Akuntansi : Perancangan, Proses, Dan Penerapan .Yogyakarta : andi

[11] Mardi. 2011. Sistem Informasi Akuntansi. Bogor : Ghalia Indonesia

[12] Soemarso S.R. 2009. Akuntansi Suatu Pengantar jilid 1. Edisi 5. Jakarta : Salemba Empat 